Article

\title{
The Effect of an Edible Coating with Tomato Oily Extract on the Physicochemical and Antioxidant Properties of Garambullo (Myrtillocactus geometrizans) Fruits
}

\author{
César Uriel López-Palestina ${ }^{1}{ }^{10}$, César Leobardo Aguirre-Mancilla ${ }^{1}$, Juan Carlos Raya-Pérez ${ }^{1}$, \\ Juan Gabriel Ramírez-Pimentel ${ }^{1}$, Jorge Gutiérrez-Tlahque ${ }^{2}(1)$ and \\ Alma Delia Hernández-Fuentes ${ }^{3, *}$ \\ 1 Tecnológico Nacional de México/I. T. Roque, km. 8 Carretera Celaya-Juventino Rosas, Celaya C.P. 38110, \\ Guanajuato, Mexico; clopez_17p@outlook.com (C.U.L.-P.); ceaguirre@itroque.edu.mx (C.L.A.-M.); \\ juraya@itroque.edu.mx (J.C.R.-P.); garamirez@itroque.edu.mx (J.G.R.-P.) \\ 2 Tecnológico Nacional de México/I. T. de Zitácuaro, Av. Tecnológico No. 186 Manzanillos, H. Zitácuaro C.P. \\ 61534, Michoacán, Mexico; jorgegutierrez111@hotmail.com \\ 3 Instituto de Ciencias Agropecuarias, Universidad Autónoma del Estado de Hidalgo, Av. Universidad Km. 1, \\ Rancho Universitario, Tulancingo C.P. 43600, Hidalgo, Mexico \\ * Correspondence: hfad@hotmail.com; Tel.: +52-775-75-60-678
}

Received: 9 October 2018; Accepted: 1 November 2018; Published: 3 November 2018

check for updates

\begin{abstract}
The Myrtillocactus geometrizans (Mart. ex. Pfeiff.) fruit, locally called garambullo, is an important source of bioactive compounds, mainly betalains, polyphenols, and ascorbic acid. However, information on the application of post-harvest technologies that prolong the shelf life of the fruits is still insufficient. The objective of the present research was to evaluate the effect of a gelatin coating incorporating $0 \%, 1 \%$, or $3 \%$ tomato oily extract (TOE), compared to a control (without coating), on the physicochemical and antioxidant properties of garambullo fruits stored for 15 days at $5{ }^{\circ} \mathrm{C}$. The gelatin coatings with TOE significantly $(p \leq 0.05)$ delayed changes in weight loss, brix degrees, titratable acidity and $\mathrm{pH}$, compared to the control during storage. Fruits coated with TOE-gelatin had a higher content of betalains, ascorbic acid, total phenols, and flavonoids. The results showed that a higher concentration of phytochemicals increased antioxidant activity in vitro; the maximum values found for Trolox equivalents per $\mathrm{kg}$ of fresh weight were 10.46 and $17.65 \mathrm{mM}$ for the 2,2'-diphenyl-1-picrylhydrazyl (DPPH) and Trolox Equivalent Antioxidant Capacity Method (TEAC) tests, respectively. The gelatin coating with TOE-3\% (COTE-3\%) reduced water loss by 1.66 times, compared to the control. In addition, the fruits covered with COTE-3\% showed the highest concentration of bioactive compounds during storage.
\end{abstract}

Keywords: Myrtillocactus geometrizans; edible coating; shelf life; bioactive; compounds; antioxidants

\section{Introduction}

Myrtillocactus geometrizans (Mart. ex. Pfeiff.) is an endemic cactus that presents Crassulacean acid metabolism photosynthesis; it grows in the arid and semi-arid areas of Mexico. This species produces an edible fruit, commonly called 'garambullo'. The fruit is globular in shape, with a diameter of $1.5 \mathrm{~cm}$. The fruit pulp has a soft and juicy consistence, and is red to a darker purple [1]. Its sensory properties make it a favorite with the locals [2]. Nevertheless, information about the fruit's physicochemical properties, bioactive compounds, and antioxidant activity is limited. There are no established parameters that allow the identification of the optimum ripening of the fruit for harvesting; 
therefore, the harvest criteria are based on the experience of local collectors [2,3]. Research has shown that garambullo is an important source of bioactive compounds (such as vitamin $C$ and betalains) and has considerable amounts of simple phenolic compounds (such as gallic acid) and flavonoids (like rutin and quercetin) [3,4]. These phytochemicals have been related to outstanding antioxidant activity in comparison with other fruits of common consumption such as cherry, raspberry, strawberry, and blueberry [5].

Despite the nutritional and functional properties of garambullo, it does not meet the market demand for functional foods [1]. One of the reasons is the rapid perishability of the fruit, in addition to the fact that post-harvest technologies extending the shelf life of the fruit are not applied. Due to the increased sales price of fresh fruit, refrigeration is used as a means of preservation; however, storage at $5{ }^{\circ} \mathrm{C}$ only prolongs the fruit's shelf life by five days. Local producers, thus, seek to make jams, ice cream, juices, and dehydrated fruits [1]. A preliminary study observed that fruit quality is considerably decreased by means of water loss at low temperature, deteriorating product appearance. In order to preserve garambullo, Correa-Bentazo et al. [6] applied a sodium caseinate coating to the fruit; however, the process failed to provide an efficient barrier to oxygen entry, and phenolic compound degradation was observed. Gelatin is thus emerging as an edible coating option that offers better oxygen and light barrier properties, in addition to easy availability, low cost and capacity as a carrier of functional ingredients $[7,8]$. Gelatin has been successfully used as a coating for fruits such as strawberries [9], mangoes [10], oranges [11], and bananas [12]. Gelatin coatings could also contain extracts of aloe vera, green tea, white tea, as well as monoterpenes such as geraniol and thymol, which are incorporated to prolong the shelf-life of orange and strawberry $[9,11]$.

Tomato (Solanum lycopersicum), is an important source of antioxidant compounds, particularly lycopene and $\beta$-carotene $[13,14]$. These pigments have been used as functional ingredients in edible gelatin-based coatings, improving mechanical, antioxidant, and UV/visible light barrier properties [15,16]. Linseed oil, due to its lipophilic characteristics, can be used as a means of extracting non-polar compounds from tomato fruits (carotenoids), and is also an important source of alpha-linolenic acid and lignans, which are mainly responsible for giving the oil good antioxidant activity [17]. However, an edible coating enriched with tomato oily extract has not been evaluated as a bioactive component to promote shelf life in fruits. The objective of this work was to evaluate the effect of a gelatin-based coating with tomato oily extract on the physicochemical and antioxidant properties of garambullo fruit during refrigerated storage.

\section{Materials and Methods}

\subsection{Materials}

Bovine gelatin was purchased from Fermont (Productos Químicos Monterrey S.A. de C.V., Monterrey, Nuevo León, México). Phenolphthalein, sodium hydroxide, aluminum trichloride hexahydrate, sodium nitrite, potassium sulphate, sodium carbonate, metaphosphoric acid, potassium persulfate, chloroform, methanol, glycerol, sorbitol and linseed oil were obtained from J.T Baker S.A de C.V. (Avantor Performance Materials, Ecatepec, Estado de México, México). 3,5-di-terc-4-butylhydroxytoluene (BHT), Gallic acid, 2,6-dichlorophenol-indophenol, 2,2'-diphenyl-1-picrylhydrazyl (DPPH), Trolox (6-hydroxy-2,5, 7,8-tetramethylchroman-2-carboxylic acid), 2,2'-azinobis-(3-ethylbenzthiazolin-6-sulfonic acid) (ABTS), L-ascorbic acid, rutin y Folin-Ciocalteau were purchased from Sigma-Aldrich (Sima-Aldrich Química SA de CV, Toluca, Estado de México, México). All solutions were prepared with Milli Q grade deionized water (resistivity > $18 \mathrm{M} \Omega \cdot \mathrm{cm}$; Millipore, Bedford, MA, USA).

\subsection{Biological Material}

Garambullo fruits (M. geometrizans), were collected in Tetepango, Hidalgo, Mexico in the fourth week of July 2018. They were selected by size (approximately $1.5 \mathrm{~cm}$ in diameter), globular shape, 
physiological maturity (the pulp was gel-like and bluish in color), and absence of physical damage. The fruits were washed and disinfected with a colloidal silver suspension $(0.35 \% p / v)$ before treatment.

\subsection{Preparation of the Tomato Oily Extract}

The tomato (Solanum lycopersicum) oily extract was prepared by grinding fresh ripe fruits (Osterizer blender, model BLSTBC4129-013, Toluca, Mexico State, Mexico México) with raw linseed oil in a 2:1 $(w / v)$ ratio, with $0.05 \%$ BHT. The mixture was subjected into an ultrasonic bath (Ultrasonic Cleaner, Mod. 32V118A, Freeport, IL, USA) for $30 \mathrm{~min}$ at $30^{\circ} \mathrm{C}$ and $40 \mathrm{kHz}$ frequency. Water was added in a ratio of 2:1 $(w / v)$ and stirred in a vortex for $10 \mathrm{~min}$. The mixture was centrifuged at $15,000 \times g$, $10 \mathrm{~min}$ (Thermo Scientific, Mod. ST 16R, Waltham, MA, USA) to separate oily and aqueous fractions. Finally, the top layer was collected as the tomato oily extract (TOE).

\subsection{Edible Coating Formula}

The edible coating was made according to a formula by Alparslan et al. [18], with modifications. The gelatin coating concentration was prepared as $8 \mathrm{~g}$ per $100 \mathrm{~mL}$ in distilled water. To the gelatin solution, glycerol (15 g per $100 \mathrm{~g}$ of gelatin) and sorbitol (10 g per $100 \mathrm{~g}$ of gelatin) were added as plasticizers. The solution was then mixed at $45^{\circ} \mathrm{C}$ for $30 \mathrm{~min}$. The tomato oily extract was added to the coating solution in a proportion of $0 \%, 1 \%$ or $3 \%(v / v)$. To stabilize the coatings containing TOE (film solution), a volume of $25 \%$ Tween 80 was added (according to the portion of TOE used). The film solutions were homogenized in Ultra Turrax (IKA T25, DS1, Wilmington, NC, USA); homogenization speed was $2 \mathrm{~min}$ at $8000 \mathrm{rpm}, 2 \mathrm{~min}$ at $1400 \mathrm{rpm}$ and $1 \mathrm{~min}$ at 17,500 rpm for $1 \mathrm{~min}$ to avoid air bubbles in the coating elaboration.

The coating formulation offered four results: control (fruits without coating); gelatin coating solution without TOE (COTE-0\%); film solution with 1\%-TOE (COTE-1\%), and film solution with $3 \%$-TOE (COTE-3\%). The fruits were immersed in the respective coating solution for $30 \mathrm{~s}$ and then dried at room temperature for $15 \mathrm{~min}$. They were stored at a temperature of $5 \pm 1{ }^{\circ} \mathrm{C}$ and at $95 \% \mathrm{RH}$ for $0,5,10$ or 15 days.

\subsection{Sample Preparation}

To evaluate bioactive compounds, samples were frozen at $-70{ }^{\circ} \mathrm{C}$ (ultra-low temperature freezer Thermo Scientific 303, USA) for one week and then lyophilized at $133 \times 10^{-3} \mathrm{mBar}$ and at $-40^{\circ} \mathrm{C}$ (Model 79480 LABCONCO, Kansas City, MO, USA). For analysis, the lyophilized fruits were ground using a knife grinder (Grindomix, Retsch GM 200, Haan, Germany) at 9000 rpm for 1 min to obtain a $150 \mu \mathrm{m}$ particle size [19].

\subsection{Weight Loss}

Fruit weight was evaluated with a digital balance (Lab-Tech, model ADP 2100L, Guadalajara, Jalisco, México). Before each treatment was applied and after each storage time (5, 10 or 15 days), the fruits were weighed to obtain accumulated weight loss as compared to its initial weight. The results were expressed as percentage.

\subsection{Brix Degree, Titratable Acidity and $p H$}

Brix degree $\left({ }^{\circ}\right.$ Brix $)$ were determined according to the AOAC 920.151 method [20] using a digital refractometer (PR-101, ATAGO Co. Ltd., Minato, Tokyo, Japan) with a scale of 0-45\%. Titratable acidity (TA) was determined using AOAC method 942.15 (AOAC, 1995); the results were expressed as percentage. $\mathrm{pH}$ values were measured using a digital pHmeter (HI 2211, Hanna Instruments Inc., Leighton Buzzard, UK). 


\subsection{Color}

Fruit color attributes (values of $L^{*}, a^{*}$ and $b^{*}$ ) were measured using a HunterLab colorimeter (Minolta, CM508d, Minolta Camera Co., Ltd., Osaka, Japan). They were identified by examining the middle part of each fruit, according to Monroy-Gutiérrez et al. [21]; five fruits per experimental unit was measured. The values of $a^{*}$ (red-green) and $b^{*}$ (yellow-blue) were used to calculate chroma values $\left(C^{*}\right)$ and hue angle $\left({ }^{\circ} h\right)$.

\subsection{Betalains Content}

Betalains concentration was determined spectrophotometrically according to Guzmán-Maldonado et al. [3], with modifications. Lyophilized fruits $(0.1 \mathrm{~g})$ were mixed with $10 \mathrm{~mL}$ of $50 \%$ methanol $(v / v)$. The samples were sonicated in an ultrasonic bath (Ultrasonic Cleaner, Mod. 32V118A, Freeport, IL, USA), for 15 min at $40 \mathrm{kHz}$ frequency. Subsequently, the samples were centrifuged at 10,000 $\times g, 10 \mathrm{~min}$ (Thermo Scientific, Mod. ST 16R, Waltham, MA, USA). Absorbance was measured at $537 \mathrm{~nm}, 476 \mathrm{~nm}$, and $600 \mathrm{~nm}$ (Spectrophotometer model 6715 UV/Vis, Jenway, Techne Inc., Staffordshire, UK). Total content of betalains (TCB) was calculated by the equation: TCB $\left[\mathrm{mg} \mathrm{L}^{-1}\right]=\left[(\mathrm{A} \times \mathrm{DF} \times \mathrm{MW} \times 1000) \times(\varepsilon \times 1)^{-1}\right]$, where $A$ is the absorbance value, DF is the dilution factor, and 1 is the length of the cell $(1 \mathrm{~cm})$. For the quantification of betacyanins and betaxanthins, molecular weight (MW) was used and the molar extinction coefficients $(\varepsilon)$ of betanin $\left(\mathrm{MW}=550 \mathrm{~g} \mathrm{~mol}^{-1}, \varepsilon=60000 \mathrm{~L} \mathrm{~mol}^{-1} \mathrm{~cm}^{-1}\right.$, maximum absorption $=537 \mathrm{~nm})$ and indicaxanthin $\left(\mathrm{MW}=308 \mathrm{~g} \mathrm{~mol}^{-1}, \varepsilon=48,000 \mathrm{~L} \mathrm{~mol}^{-1} \mathrm{~cm}^{-1}\right.$, absorption maximum $=476 \mathrm{~nm}$ ).

\subsection{Ascorbic Acid Content}

Ascorbic acid determination was performed according to a method by Dürüst et al. [22], with modifications. Fresh fruits $(0.1 \mathrm{~g})$ were mixed with $10 \mathrm{~mL}$ of metaphosphoric acid solution at 3\% $(v / v)$. The samples were sonicated in an ultrasonic bath (Mod. 32V118A, Freeport, IL, USA) for 15 min at $40 \mathrm{kHz}$ frequency. The samples were centrifuged at $10,000 \times \mathrm{g}$ for $10 \mathrm{~min}$. $2 \mathrm{~mL}$ of supernatant was added to $2 \mathrm{~mL}$ of buffer $\mathrm{pH} 4$ (glacial acetic acid: sodium acetate at 5\% $(p / v), 1: 1), 3 \mathrm{~mL}$ of dichloroindophenol, and $15 \mathrm{~mL}$ of xylene, and mixed vigorously. Absorbance was measured on a spectrophotometer (model 6715 UV/Vis, Jenway, Techne Inc., Staffordshire, UK) at 520 nm. The results were expressed in $\mathrm{mg}$ of ascorbic acid per $\mathrm{kg}$ of fresh weight.

\subsection{Preparation of Methanol Extracts}

The lyophilized samples $(0.1 \mathrm{~g})$ were suspended in $10 \mathrm{~mL}$ of $70 \%$ methanol $(v / v)$ [6], and vortexed for $5 \mathrm{~min}$, after which the mixes were sonicated in an ultrasonic bath (Ultrasonic Cleaner, Mod. 32V118A, Freeport, IL, USA), for $30 \mathrm{~min}$ at $30^{\circ} \mathrm{C}$ and at $40 \mathrm{kHz}$ frequency. Subsequently, the samples were centrifuged at $10,000 \times g, 10 \mathrm{~min}$ (Thermo Scientific, Mod. ST 16R, Waltham, MA, USA). The supernatant was recovered to determine the content of total phenols, flavonoids, and antioxidant activity [19].

\subsection{Total Phenols and Flavonoids}

Total phenols content and total flavonoids were determined according to Rosales et al. [23]. Total phenols were determined spectrophotometrically using the Folin-Ciocalteu reagent. A supernatant $(0.5 \mathrm{~mL})$ was mixed with $0.5 \mathrm{~mL}$ of Folin-Ciocalteu reagent $(50 \% v / v$ in distilled water), $1.5 \mathrm{~mL}$ of sodium carbonate solution ( $2 \% \mathrm{w} / \mathrm{v}$ in water) and $2.5 \mathrm{~mL}$ of distilled water; the mix was kept in complete darkness for $60 \mathrm{~min}$, following which absorbance was measured at $725 \mathrm{~nm}$. Flavonoid content was determined by mixing aliquots of the supernatant with $2 \mathrm{~mL}$ of distilled water and $0.15 \mathrm{~mL}$ of $\mathrm{NaNO}_{2}\left(5 \%\right.$ w/v). After $5 \mathrm{~min}, 0.15 \mathrm{~mL}$ of $\mathrm{AlCl}_{3} \cdot 6 \mathrm{H}_{2} \mathrm{O}$ solution $(10 \% w / v)$ was added; the mixture was incubated at room temperature for another $5 \mathrm{~min}$, then $1 \mathrm{~mL}$ of $\mathrm{NaOH}$ solution $(1 \mathrm{M})$ was added. The solution was kept for a further $15 \mathrm{~min}$ in darkness, and absorbance was measured at 
$415 \mathrm{~nm}$. The content of total phenols and flavonoids were expressed as $\mathrm{mg}$ of gallic acid equivalents (GAE) and $\mathrm{mg}$ of routine equivalents (RE) per $\mathrm{kg}$ of fresh weight, respectively.

\subsection{Antioxidant Activity}

\subsubsection{DPPH Free Radical Scavenging Assay}

For DPPH, the Brand-Williams et al. [24] method was performed: To $0.3 \mathrm{~mL}$ of the supernatant was added $2.7 \mathrm{~mL}$ of a cold methanol solution with DPPH $\left(6 \times 10^{-5} \mathrm{M}\right)$; the mix was incubated in darkness for $60 \mathrm{~min}$ at $4{ }^{\circ} \mathrm{C}$, and absorbance at $517 \mathrm{~nm}$ was measured. The results were expressed in $\mathrm{mM}$ of Trolox equivalents (TE) per $\mathrm{kg}$ of fresh weight.

\subsubsection{Trolox Equivalent Antioxidant Capacity Method (TEAC)}

For the TEAC method [25], the ABTS ${ }^{\bullet+}$ radical was obtained by the reaction of ABTS $(7 \mathrm{mM})$ with potassium persulfate $(2.45 \mathrm{mM})$, incubated at room temperature $\left(25 \pm 2{ }^{\circ} \mathrm{C}\right)$ in darkness for $16 \mathrm{~h}$. Once the radical $\mathrm{ABTS}^{\bullet+}$ was formed, it was diluted with methanol until absorbance value of $0.700 \pm 0.1$ at $734 \mathrm{~nm}$ were obtained. The samples reacted with the ABTS ${ }^{\bullet+}$ for 6 min and absorbance was measured at $734 \mathrm{~nm}$. The results were expressed in mmol of Trolox equivalent per $\mathrm{kg}$ of fresh weight.

\subsection{Statistic Analysis}

The experiment was established in a completely random factorial design consisting of two factors: type of coating (control, COTE- $0 \%$, COTE- $1 \%$ y COTE-3\%) and storage time (0, 5, 10 y 15 days). The experimental unit was 25 fruits, with 5 replicates for each treatment. The statistical comparisons of the results were subjected to two-way ANOVA using SAS 9.4 software (Cary, NC, USA). The significant differences $(p<0.05)$ were analyzed by the Tukey test.

\section{Results and Discussion}

\subsection{Weight Loss}

Significant differences were observed due to the effect of edible coatings with TOE and storage time (Table 1). Weight loss was more affected by storage time and reached its maximum on day 15. In addition, a greater weight loss was observed in the control fruits (uncoated) with respect to the coated fruits. Weight loss in fruits is associated with water loss by metabolic processes such as transpiration and respiration, and the rate of water loss depends on the pressure gradient of the water in the fruit tissue and the surrounding atmosphere, and the storage temperature $[11,26]$. The COTE- $3 \%$ treatment prevented greater weight loss, with 1.66 times less weight loss compared to the control. On the other hand, gelatin as an edible coating reduces weight loss, but is more effective with TOE, as observed in the following treatments: $5 \times$ COTE $-1 \%, 10 \times$ COTE- $1 \%$ and $15 \times$ COTE-5\% (Table 1 ). This suggests that TOE improves the water vapor barrier properties of the coating. This is because TOE has hydrophobic properties and reduces the transference of water vapor through the coating [27]. According to the literature, the effect of gelatin coating with TOE produced similar effects in other studies, where gelatin has proven to be more effective when mixed with hydrophobic components [28]. Based on the results shown in this research, it is inferred that gelatin coatings with TOE retard the metabolic processes of the fruit and, therefore, extend its shelf life in cold storage. 
Table 1. Effect of edible coating incorporated with tomato oily extract and storage period on weight loss, $\mathrm{Bx}, \mathrm{pH}$, and titratable acidity of Myrtillocactus geometrizans fruits during storage.

\begin{tabular}{|c|c|c|c|c|c|}
\hline Factors & Levels & Weight Loss (\%) & Bx $(\%)$ & $\mathrm{pH}$ & Titratable Acidity (\%) \\
\hline \multirow{4}{*}{ Edible coating } & Control & $11.44^{\mathrm{a}}$ & $20.69^{a}$ & $4.00^{\mathrm{a}}$ & $8.24^{c}$ \\
\hline & COTE-0\% & $9.64^{b}$ & $20.36^{a}$ & $3.97 \mathrm{ba}$ & $8.64^{\mathrm{c}}$ \\
\hline & COTE- $1 \%$ & $8.19^{\mathrm{c}}$ & $18.78^{b}$ & $3.95 \mathrm{bc}$ & $9.24^{b}$ \\
\hline & COTE-3\% & $6.88^{\mathrm{d}}$ & $17.19^{c}$ & $3.91^{\mathrm{c}}$ & $9.70^{\mathrm{a}}$ \\
\hline \multirow{4}{*}{ Storage period } & 0 & $0.00^{\mathrm{d}}$ & $12.77^{\mathrm{d}}$ & $3.79^{\mathrm{d}}$ & $11.09^{\mathrm{a}}$ \\
\hline & 5 & $3.43^{c}$ & $16.75^{c}$ & $3.92^{\mathrm{c}}$ & $9.48^{\mathrm{b}}$ \\
\hline & 10 & $11.67^{\mathrm{b}}$ & $19.75^{b}$ & $3.98^{b}$ & $8.29^{c}$ \\
\hline & 15 & $21.04^{\mathrm{a}}$ & $27.75^{a}$ & $4.15^{\mathrm{a}}$ & $6.95^{\mathrm{d}}$ \\
\hline \multicolumn{6}{|c|}{ Interaction } \\
\hline Storage Days & Edible Coating & & & & \\
\hline 0 & Initial & $0.00^{1}$ & $12.77^{f}$ & $3.79 \mathrm{~g}$ & $11.09^{a}$ \\
\hline 5 & Control & $5.59^{\mathrm{h}}$ & 18.00 de & 3.96 fde & $8.63^{\mathrm{ecd}}$ \\
\hline 5 & COTE- $0 \%$ & $3.58^{\mathrm{i}}$ & 18.00 de & 3.95 fde & $9.47^{b c d}$ \\
\hline 5 & COTE-1\% & $2.73^{j}$ & $17.33^{\mathrm{e}}$ & $3.90 \mathrm{fg}$ & $9.73 \mathrm{bc}$ \\
\hline 5 & COTE-3\% & $1.82^{\mathrm{k}}$ & $13.67^{\mathrm{f}}$ & $3.86^{\mathrm{fg}}$ & $10.11^{\text {ba }}$ \\
\hline 10 & Control & $14.43^{\mathrm{e}}$ & $20.33^{c}$ & $4.05^{\mathrm{bdec}}$ & $7.25 \mathrm{gf}$ \\
\hline 10 & COTE- $0 \%$ & $12.12^{\mathrm{e}}$ & $20.00^{c}$ & $3.99 \mathrm{fdec}$ & $7.76^{\text {ef }}$ \\
\hline 10 & COTE- $1 \%$ & $11.41^{\mathrm{f}}$ & $19.67 \mathrm{dc}$ & 3.97 fde & $8.70^{\text {ecd }}$ \\
\hline 10 & COTE-3\% & $8.72^{g}$ & $\begin{array}{l}19.00 \\
\text { dce }\end{array}$ & $3.92 \mathrm{feg}$ & $9.47^{b c d}$ \\
\hline 15 & Control & $25.73^{a}$ & $31.67^{\mathrm{a}}$ & $4.22^{\mathrm{a}}$ & $5.99^{\mathrm{h}}$ \\
\hline 15 & COTE- $0 \%$ & $22.85^{b}$ & $30.67^{a}$ & $4.15^{\mathrm{ba}}$ & $6.26^{\mathrm{gh}}$ \\
\hline 15 & COTE- $1 \%$ & $18.61^{\mathrm{c}}$ & $25.33^{b}$ & $4.13^{\mathrm{bac}}$ & $7.4^{\mathrm{f}}$ \\
\hline 15 & COTE-3\% & $16.96^{\mathrm{d}}$ & $23.33^{b}$ & $4.08^{\mathrm{bdac}}$ & 8.12 efd \\
\hline
\end{tabular}

Means with different letters in the same column indicate significant differences according to Tukey's test $(<0.05)$. COTE: coating with tomato oily extract.

\subsection{Brix Degrees $(B x)$, Titratable Acidity (TA) and $p H$}

Changes in the $\mathrm{Bx}, \mathrm{TA}$ and $\mathrm{pH}$ of garambullo fruits during storage, with and without gelatin-based coating with TOE, are shown in Table 1 . Bx was significantly affected by the coating, storage period, and their interactions. All the fruits (coated and uncoated) showed an increase of Bx; this may be due to the fact that during the maturation of the fruits, metabolic processes occur, such as the degradation of pectin and hydrolysis of the starch as in pitahaya fruits (Hylocereus undatus) [29]. This can also be attributed to a greater loss of water due to the lack of protective barriers [26]. However, the COTE- $1 \%$ and COTE-3\% coating significantly delayed the Bx increase of garambullos during refrigerated storage; this may be due to the aforementioned coatings delaying ripening and avoiding excessive loss of water. The results showed that TA decreased, while the $\mathrm{pH}$ increased gradually with increased storage period in both coated and uncoated fruits. On the other hand, TA decreased more slowly in coated fruits than the uncoated ones (control). Reports show that the edible coating can decrease gas permeability on fruit surfaces, leading to a lower respiration rate, slight change in TA for coated fruits and, as a result, a slight increase in $\mathrm{pH}$ [11].

In general, a lower change in $\mathrm{Bx}, \mathrm{pH}$ and $\mathrm{TA}$ was observed in the fruits of garambullo during storage due to the effect of the coating with COTE-3\%; with regard to storage time, changes were observed after 5 days. Uncoated fruits (treatments $5 \times$ Control, $10 \times$ Control, $15 \times$ Control) had a shorter shelf life, with respect to the fruits of garambullo with coating during the storage period.

Previous studies have shown that the use of gelatin as an edible coating could be responsible for a lower change in the values of $\mathrm{Bx}, \mathrm{TA}$ and $\mathrm{pH}$ when applied to fruits such as mango [10], peppers [26], and oranges [11] (compared to the same uncoated fruits). In this study, the effect of the gelatin-based coating was enhanced to a higher TOE content (Table 1). Therefore, we can state that the application of 
gelatin-based coatings with TOE on garambullo reduces respiration and consequently the expense of organic acids, prolonging the life of the fruit.

The values of $\mathrm{Bx}, \mathrm{TA}$ and $\mathrm{pH}$ for garambullo fruits in its initial stages (at the time of harvest) were similar to the ones reported by Guzmán-Maldonado et al. [3] and Santiago-Mora et al. [4]. This confirms that the physicochemical parameters are similar, despite the scarce post-harvest information related to the fruit.

\subsection{Color}

Color parameters in the garambullo fruits were significantly affected by the storage period and not by the effect of the coating (Table 2). It is observed that on days 10 and 15 of storage, the fruits presented the highest values of hue. The same behavior was observed in the last days of storage in interaction with the coatings. The hue angle indicates that fruits have a dark red hue, which is given by a low chromaticity. The color in the garambullo fruits is derived from the presence of betalains, just like in other cacataceas like Opuntia dilleniid [30], and these pigments, compared with anthocyanins, do not give bright colors [31]. This may explain luminosity $(L)$ values presented by the garambullo fruits. According to the above, it can be explained that the increase in the coloring of the fruits is due to the increase in the concentration of betalains in the last days of storage (Table 3). The color parameters of studied fruits showed similar values of luminosity and chromaticity, but not for the values of the hue angle, as reported by Herrera-Hernández et al. [2]; values found in this research were a bit higher than the values reported by Guzmán-Maldonado et al. [3].

Table 2. Effect of edible coating incorporated with tomato oily extract and storage period on color of Myrtillocactus geometrizans fruits during storage.

\begin{tabular}{|c|c|c|c|c|c|c|}
\hline Factors & Levels & $L$ & $a$ & $b$ & Croma & hue \\
\hline \multirow{4}{*}{ Edible coating } & Control & $28.02^{a}$ & $6.66^{\mathrm{ba}}$ & $13.51^{\text {ba }}$ & $15.51^{\mathrm{ba}}$ & $60.90^{a}$ \\
\hline & COTE- $0 \%$ & $30.28^{a}$ & $7.66^{\mathrm{b}}$ & $12.41^{\mathrm{b}}$ & 14.74 ba & $58.23^{a}$ \\
\hline & COTE-1\% & $30.83^{a}$ & $5.62^{a}$ & $11.95^{b}$ & $13.32^{b}$ & $64.06^{\mathrm{a}}$ \\
\hline & COTE-3\% & $27.80^{a}$ & $7.18^{\text {ba }}$ & $15.14^{\mathrm{a}}$ & $16.95^{\mathrm{a}}$ & $64.09^{a}$ \\
\hline \multirow{4}{*}{ Storage period } & 0 & $35.96^{a}$ & $5.98^{b}$ & $8.52^{b}$ & $10.44^{\mathrm{c}}$ & $55.53^{b}$ \\
\hline & 5 & $26.45^{b}$ & $9.71^{\mathrm{a}}$ & $15.66^{\mathrm{a}}$ & $18.84^{\mathrm{a}}$ & $56.81^{b}$ \\
\hline & 10 & $27.18^{b}$ & $6.03^{b}$ & $13.91^{\mathrm{a}}$ & $15.33^{b}$ & $65.35^{\mathrm{a}}$ \\
\hline & 15 & $27.33^{b}$ & $5.40^{\mathrm{b}}$ & $14.92^{\mathrm{a}}$ & $15.92^{b}$ & $69.59^{a}$ \\
\hline \multicolumn{7}{|c|}{ Interaction } \\
\hline Storage Days & Edible Coating & & & & & \\
\hline 0 & Initial & $35.96^{\mathrm{a}}$ & $5.98^{b c}$ & $8.52^{\mathrm{d}}$ & $10.44^{\mathrm{d}}$ & $55.53^{\mathrm{ba}}$ \\
\hline 5 & Control & $27.46^{\text {ba }}$ & $9.20^{\mathrm{a}}$ & $11.73 \mathrm{bdac}$ & $15.76^{\text {bdac }}$ & $46.95^{b}$ \\
\hline 5 & COTE- $0 \%$ & 27.25 ba & $11.65^{\mathrm{bac}}$ & $16.24 \mathrm{ba}$ & $20.14^{\text {ba }}$ & 53.98 ba \\
\hline 5 & COTE-1\% & $25.06^{b}$ & $7.31 \mathrm{bac}$ & $16.07^{\mathrm{bac}}$ & 17.79 bac & $65.31^{a}$ \\
\hline 5 & COTE-3\% & $26.03^{b}$ & $10.67^{\text {ba }}$ & $18.62^{a}$ & $21.65^{\mathrm{a}}$ & 60.99 ba \\
\hline 10 & Control & $24.45^{\mathrm{b}}$ & $5.77^{\mathrm{c}}$ & $16.72^{\mathrm{bac}}$ & $17.79 \mathrm{bac}$ & $69.98^{a}$ \\
\hline 10 & COTE-0\% & $29.33^{b a}$ & $7.31^{\mathrm{bac}}$ & $11.08 \mathrm{bdc}$ & $13.40^{b d c}$ & $55.72 \mathrm{ba}$ \\
\hline 10 & COTE-1\% & $31.00 \mathrm{ba}$ & $4.70^{\mathrm{c}}$ & $11.52 \mathrm{dc}$ & $12.48^{\mathrm{dc}}$ & $66.93^{a}$ \\
\hline 10 & COTE-3\% & $23.94^{b}$ & $6.35^{b c}$ & $16.33^{\mathrm{bdac}}$ & $17.64^{\mathrm{bdac}}$ & $68.79^{a}$ \\
\hline 15 & Control & $24.20^{b}$ & $5.70^{\mathrm{c}}$ & $17.06^{\mathrm{bac}}$ & $18.06^{\mathrm{bac}}$ & $71.13^{a}$ \\
\hline 15 & COTE-0\% & $28.57^{\mathrm{ba}}$ & $5.70^{\mathrm{c}}$ & $13.82 \mathrm{bdac}$ & $14.98^{\mathrm{bdac}}$ & $67.70^{\mathrm{a}}$ \\
\hline 15 & COTE-1\% & $31.28^{b a}$ & $4.48^{\mathrm{c}}$ & $11.70 \mathrm{bc}$ & $12.58^{b c}$ & $68.46^{\mathrm{a}}$ \\
\hline 15 & COTE-3\% & $25.26^{b}$ & $5.73^{c}$ & $17.09^{\mathrm{bac}}$ & $18.05^{\mathrm{bac}}$ & $71.05^{a}$ \\
\hline
\end{tabular}

Means with different letters in the same column indicate significant differences according to Tukey's test $(<0.05)$. COTE: coating with tomato oily extract. 
Table 3. Effect of edible coating incorporated with tomato oily extract and storage period on betanin, indicaxanthin, total betalains and ascorbic acid contents of Myrtillocactus geometrizans fruits during storage.

\begin{tabular}{|c|c|c|c|c|c|}
\hline Factors & Levels & $\begin{array}{c}\text { Betanin } \\
\left(\mathrm{mg} \mathrm{Kg}^{-1}\right)\end{array}$ & $\begin{array}{l}\text { Indicaxanthin } \\
\left(\mathrm{mg} \mathrm{Kg}^{-1}\right)\end{array}$ & $\begin{array}{l}\text { Total Betalains } \\
\left(\mathrm{mg} \mathrm{Kg}^{-1}\right)\end{array}$ & $\begin{array}{l}\text { Ascorbic Acid } \\
\left(\mathrm{mg} \mathrm{Kg}^{-1}\right)\end{array}$ \\
\hline \multirow{4}{*}{ Edible coating } & Control & $125.50^{d}$ & $57.38^{c}$ & $182.88^{d}$ & $222.34^{c}$ \\
\hline & COTE- $0 \%$ & $129.60^{c}$ & $58.15^{c}$ & $187.76^{c}$ & $234.93^{c}$ \\
\hline & COTE-1\% & $130.87^{b}$ & $60.91^{b}$ & $191.78^{b}$ & $256.64^{b}$ \\
\hline & COTE-3\% & $140.29^{a}$ & $62.42^{\mathrm{a}}$ & $202.71^{a}$ & $281.39^{a}$ \\
\hline \multirow{4}{*}{ Storage period } & 0 & $106.22^{d}$ & $44.12^{\mathrm{d}}$ & $150.33^{d}$ & $308.15^{b}$ \\
\hline & 5 & $128.56^{c}$ & $60.35^{c}$ & $188.91^{\mathrm{c}}$ & $339.97^{\mathrm{a}}$ \\
\hline & 10 & $142.47^{b}$ & $64.11^{b}$ & $206.58^{b}$ & $275.33^{c}$ \\
\hline & 15 & $149.02^{\mathrm{a}}$ & $70.28^{a}$ & $219.31^{a}$ & $71.86^{\mathrm{d}}$ \\
\hline \multicolumn{6}{|c|}{ Interaction } \\
\hline Storage Days & Edible Coating & & & & \\
\hline 0 & Initial & $106.22^{\mathrm{h}}$ & $44.12^{\mathrm{h}}$ & $150.33^{\mathrm{h}}$ & $308.15^{\mathrm{bac}}$ \\
\hline 5 & Control & $124.73 \mathrm{~g}$ & $56.92 \mathrm{~g}$ & $181.65 \mathrm{~g}$ & 332.39 ba \\
\hline 5 & COTE- $0 \%$ & $126.93^{g}$ & $57.85^{\mathrm{fg}}$ & $184.78^{\mathrm{g}}$ & $336.43^{a}$ \\
\hline 5 & COTE- $1 \%$ & $127.37^{f}$ & $61.70^{\text {ed }}$ & $189.07^{\mathrm{f}}$ & $338.45^{\mathrm{a}}$ \\
\hline 5 & COTE-3\% & $135.19^{\mathrm{e}}$ & $64.94^{\mathrm{d}}$ & $200.14^{\mathrm{e}}$ & $352.59^{a}$ \\
\hline 10 & Control & $130.02^{f}$ & $59.85^{\text {efg }}$ & $189.87^{f}$ & $241.50^{d}$ \\
\hline 10 & COTE- $0 \%$ & 140.81 ed & 61.09 ef & 201.90 ed & $269.77^{\mathrm{dc}}$ \\
\hline 10 & COTE-1\% & $141.48^{\mathrm{dc}}$ & $66.79 \mathrm{bc}$ & $208.27 \mathrm{dc}$ & $285.93^{b c d}$ \\
\hline 10 & COTE-3\% & $157.56^{b}$ & 68.72 ba & $226.28^{b}$ & 304.11 bac \\
\hline 15 & Control & $141.03^{c}$ & $68.64^{\text {bac }}$ & $209.68^{c}$ & $7.33^{\mathrm{g}}$ \\
\hline 15 & COTE- $0 \%$ & $144.45^{\mathrm{c}}$ & $69.57^{\text {ba }}$ & $214.02^{c}$ & $25.37 \mathrm{~g}$ \\
\hline 15 & COTE-1\% & $148.42^{b}$ & $71.04^{\mathrm{a}}$ & $219.45^{b}$ & $94.04^{\mathrm{f}}$ \\
\hline 15 & COTE-3\% & $162.19^{a}$ & $71.88^{a}$ & $234.07^{\mathrm{a}}$ & $160.70^{\mathrm{e}}$ \\
\hline
\end{tabular}

Means with different letters in the same column indicate significant differences according to Tukey's test $(p<0.05)$. COTE: coating with tomato oily extract.

\subsection{Betalains Content}

Total betalains content in garambullo fruits showed $70 \%$ betanin and $30 \%$ indicaxanthin (Table 3 ). Betanins and indicaxanthins provide purple-red and yellow-orange tones, respectively, responsible for the color seen in ripe garambullo fruits [32]. In Table 3, the effect of the edible coating on betalaine content is shown; significant difference was found for the indicaxanthin variable when comparing the COTE-3\% effect with respect to COTE- $1 \%$, COTE- $0 \%$, and the control. However, for the same variable, no significant difference was found when comparing COTE- $0 \%$ with the control. In the case of the variable betaninas and betalainas total, significant difference was found for all levels of the edible coating factor.

With regard to storage time, all of their evaluation levels showed significant differences for the variable betanin, indicaxanthin and total betalains, showing an increase in the content of these compounds. Total betalains content increased by $45.89 \%$ during the storage period with respect to the initial concentration.

This trend was similar to that reported by Herrera-Hernández et al. [2], who mention that storage had a positive effect on betalain synthesis in garambullo fruits. They also suggest that the synthesis of these compounds is a possible defense mechanism against stress caused by chilling injury. However, Correa-Bentazo et al. [6] reported that betalain content does not appear to change in low temperature storage conditions, including ice boxes. According to Ramírez-Ramos et al. [33] and Sumaya-Martinez et al. [34], in fruits that belongs to the family Cactaceae, such as pigmented prickly pears, the concentration of total betalain increased during storage due to the loss of water and progression in fruit maturity. Therefore, based on the results of this research, it is clear that total betalains increased due to the ripening process. 
On the other hand, as the TOE increased in the formulation of the film, the synthesis of these pigments increased. The highest content of betalains was observed at day 15 of storage in the fruits treated with $15 \times$ COTE- $1 \%$ and $15 \times$ COTE-3\%, retaining the same proportion between betanins and indicaxanthins. The proportion of betanins responsible for providing purple-red coloration is greater than in fruits of other cacti such as prickly pears [35]. Reports indicate that betalains are mainly susceptible to $\mathrm{pH}$, temperature, water activity, light, and oxygen [31,36]. Gelatin coatings with different concentrations of added TOE improve the stability of betalains content in garambullo fruits, probably due to the presence of lycopene and $\beta$-carotene in TOE, since these compounds are antioxidants that are able to inhibit reactive oxygen species [14,16,37], a causative for pigment loss [36].

\subsection{Ascorbic Acid}

Ascorbic acid content in garambullo fruits is shown in Table 3. Significant differences were observed with regard to storage time: on day 5 of storage, an increase of $10.32 \%$ of ascorbic acid was observed, while on day 15 , there was a drastic reduction of 4.73 times compared to the maximum concentration presented. The fruits with TOE edible coatings also presented significant differences with respect to the control. The fruits with the COTE- $3 \%$ coating showed the highest concentration of ascorbic acid, followed by the fruits with the COTE- $1 \%$ treatment. The ascorbic acid content of the garambullo fruits with gelatin coating without TOE (COTE-0\%) was significantly equal to the control. The gelatin without TOE in its formulation did not decrease the oxidation of ascorbic acid as shown in the fruits with the $15 \times$ COTE- $0 \%$ treatment. However, the coatings of gelatin with TOE could have reduced the oxidation of the acids in the fruits. The higher TOE content in the film formulation showed higher values in ascorbic acid content (Table 3). This was more evident on day 15 of storage, since the fruits with the $15 \times$ Control treatment showed a loss of $97.85 \%$, while the fruits with the treatment $15 \times$ COTE- $3 \%$ showed a reduction of $54.42 \%$ with respect to the content of ascorbic acid registered on the $5^{\text {th }}$ day of storage. The decrease in ascorbic acid in uncoated garambullo fruits could be attributed to the presence of $\mathrm{O}_{2}$, since ascorbic acid is highly sensitive to chemical and enzymatic oxidation; it is also susceptible to degradation by temperature and light [38]. The high content of ascorbic acid in coated fruits (gelatin added with TOE) can be attributed to a low $\mathrm{O}_{2}$ availability, which provokes a slower ripening rate and consequently a delayed senescence [10], also delaying ascorbic acid oxidation. In addition, it is likely that the antioxidant compounds present in the TOE serve as target molecules against the action of $\mathrm{O}_{2}[8,9,14,38]$. Herrera-Hernández et al. [2] reported the reduction of ascorbic acid in garambullo fruits by $68.5 \%$ during storage ( 5 days) at $5{ }^{\circ} \mathrm{C}$.

\subsection{Total Phenols and Flavonoids}

Phenolics compounds are the most important groups of secondary metabolites and bioactive compounds in plants. They are crucial for plant growth and reproduction, and are produced as a response to environmental factors (light, chilling, pollution, etc.) and to defend plants and fruits injured [9,39]. In Table 4, it can be seen that garambullos are a good source of these secondary metabolites. On the other hand, it is observed that the type of coating has a significant effect on the content of phenols and flavonoids in the fruit, since the ones treated with COTE- $1 \%$ and COTE- $3 \%$ present a higher concentration of these compounds, which indicates a greater conservation of phenols and flavonoids. Regarding storage time at $5^{\circ} \mathrm{C}$, an increase of phenols and flavonoids was observed at day 5; a reduction of the compounds was later observed, but more pronounced for the flavonoids on day 15 of the evaluation. In the combined effect, the highest concentration of phenols and flavonoids was found in fruits treated with COTE- $3 \%$ on day 5 (treatment $5 \times$ COTE- $3 \%$ ), while fruits treated with COTE- $0 \%$ and COTE- $1 \%$ presented lower values during the different days of evaluation. 
Table 4. Effect of edible coating incorporated with tomato oily extract and storage period on bioactive compounds and antioxidant activity of Myrtillocactus geometrizans fruits during storage.

\begin{tabular}{|c|c|c|c|c|c|}
\hline Factors & Levels & $\begin{array}{l}\text { Total Phenols } \\
\left(\mathrm{mg} \mathrm{GAE} \mathrm{Kg}^{-1}\right)\end{array}$ & $\begin{array}{c}\text { Flavonoids } \\
\left(\mathrm{mg} \mathrm{QE} \mathrm{Kg}^{-1}\right)\end{array}$ & $\begin{array}{c}\text { DPPH } \\
\left(\mathrm{mM} \text { TE } \mathrm{Kg}^{-1}\right)\end{array}$ & $\begin{array}{c}\text { ABTS } \\
\left(\mathrm{mM} \mathrm{TE} \mathrm{Kg}^{-1}\right)\end{array}$ \\
\hline \multirow{4}{*}{ Edible coating } & Control & $8572.43^{b}$ & $3644.59^{d}$ & $9.25^{\mathrm{d}}$ & $13.99^{\mathrm{d}}$ \\
\hline & COTE-0\% & $8670.69^{b}$ & $3726.57^{c}$ & $9.47^{c}$ & $14.58^{c}$ \\
\hline & COTE-1\% & $9200.13^{\mathrm{a}}$ & $3866.74^{b}$ & $9.77^{b}$ & $15.53^{b}$ \\
\hline & COTE-3\% & $9373.22^{a}$ & $4025.81^{\mathrm{a}}$ & $9.90^{\mathrm{a}}$ & $15.95^{\mathrm{a}}$ \\
\hline \multirow{4}{*}{ Storage period } & 0 & $8299.05^{d}$ & $5164.96^{b}$ & $9.01^{c}$ & $13.77^{c}$ \\
\hline & 5 & $9658.31^{a}$ & $5756.46^{\mathrm{a}}$ & $10.08^{a}$ & $16.24^{\mathrm{a}}$ \\
\hline & 10 & $9127.34^{b}$ & $2470.20^{c}$ & $9.68^{b}$ & $15.16^{\mathrm{b}}$ \\
\hline & 15 & $8731.78^{c}$ & $1872.08^{\mathrm{d}}$ & $9.62^{b}$ & $14.87^{b}$ \\
\hline \multicolumn{6}{|c|}{ Interaction } \\
\hline Storage Days & Edible Coating & & & & \\
\hline 0 & Initial & $8299.05^{f}$ & $5164.96^{\mathrm{e}}$ & $9.01^{\mathrm{h}}$ & $13.77^{\mathrm{hg}}$ \\
\hline 5 & Control & $9174.68^{\mathrm{dc}}$ & $5283.92^{d}$ & $9.57^{\mathrm{e}}$ & $14.76^{\mathrm{e}}$ \\
\hline 5 & COTE- $0 \%$ & $9052.50^{\mathrm{dc}}$ & $5560.54^{c}$ & $9.94 \mathrm{dc}$ & $15.43^{\mathrm{d}}$ \\
\hline 5 & COTE-1\% & $10,029.94$ ba & $6041.85^{b}$ & $10.34^{b a}$ & $17.12^{\mathrm{a}}$ \\
\hline 5 & COTE-3\% & $10,376.12^{a}$ & $6139.55^{\mathrm{a}}$ & $10.46^{\mathrm{a}}$ & $17.65^{\mathrm{a}}$ \\
\hline 10 & Control & $8557.67^{\mathrm{fe}}$ & $2348.68 \mathrm{~g}$ & $9.28 \mathrm{fg}$ & $14.12^{\mathrm{fg}}$ \\
\hline 10 & COTE-0\% & $8950.68^{\text {de }}$ & $2351.13 \mathrm{~g}$ & $9.45^{\mathrm{fe}}$ & $14.74^{\mathrm{e}}$ \\
\hline 10 & COTE-1\% & $9398.68 \mathrm{dc}$ & $2409.75 \mathrm{~g}$ & $9.93 \mathrm{bc}$ & $15.72 \mathrm{~cd}$ \\
\hline 10 & COTE-3\% & $9602.31 \mathrm{bc}$ & $2771.25^{f}$ & $10.05^{\mathrm{dc}}$ & $16.06^{\mathrm{cb}}$ \\
\hline 15 & Control & $8258.33^{f}$ & $1780.79^{j}$ & $9.16^{\mathrm{hg}}$ & $13.30^{\mathrm{h}}$ \\
\hline 15 & COTE- $0 \%$ & $8380.51^{f}$ & $1829.64^{j}$ & $9.46^{\mathrm{fe}}$ & $14.38^{\text {fe }}$ \\
\hline 15 & COTE-1\% & $9072.86^{\mathrm{dc}}$ & $1850.40^{j}$ & $9.78^{\mathrm{d}}$ & $15.50^{\mathrm{cd}}$ \\
\hline 15 & COTE-3\% & $9215.41^{\mathrm{dc}}$ & $2027.48^{h}$ & $10.07^{b c}$ & $16.31^{\mathrm{b}}$ \\
\hline
\end{tabular}

Means with different letters in the same column indicate significant differences according to Tukey's test $(<0.05)$. COTE: coating with tomato oily extract.

The variation of these metabolites could be due to the inactivation of the enzyme phenylalanine ammonia lyase (PAL), which is an important key in the synthesis and accumulation of phenolic compounds in fruits. However, this activity decreases naturally during maturation and post-harvest stages [9,39], as has also been reported for other non-climacteric fruits such as prickly pear pigmented [33] and grapes [40]. The concentration of these metabolites and their decrease during storage was similar to that reported by Herrera-Hernández et al. [2]. High content of total phenols and flavonoids was found in garambullo fruits coated with COTE- $1 \%$ and COTE- $3 \%$. When the phenolic compounds are synthesized by PAL activation, metabolites are probably preserved by gelatin coating incorporated with TOE; gelatin coatings present good oxygen barrier properties [8], which allow maintaining of cellular integrity and reduces polyphenol oxidase and other catalytic enzyme activities [6,41]. Sánchez-González et al. [39] mentioned that there is high inhibition of respiration rates and consequently, metabolic activity reduction of fruit, which is related to a reduction of oxidative stress that slows down both, tissue senescence and cellular rupture. Despite the high antioxidant activity of flavonoids compared to phenylpropanoids, some such as quercetin, myricetin, quercetagetin and delphinidin oxidize faster [42,43]. This could explain why flavonoids degraded to a greater extent in garambullos, since quercetin and myricetin have also been found in these fruits [6].

\subsection{Antioxidant Activity}

The coatings show a positive effect on the fruits of garambullo, because they have a greater antioxidant activity against the reduction of the radical $\mathrm{DPPH}^{\bullet}$ y $\mathrm{ABTS}^{\bullet+}$ compared to the control; this is more evident in fruits coated with COTE-3\% (Table 4). Regarding the effect of storage time, an increase in antioxidant activity is observed on day 5, while on days 10 and 15, a reduction occurs without significant differences between these days. In the interaction of the factors, it is shown that 
the fruits evaluated on days 10 and 15 with coatings of COTE- $1 \%$ and COTE- $3 \%$ do not present significant differences in antioxidant activity. Antioxidant activity performance during the first days of storage ( 5 and 10 days) was similar to a pattern of total phenols content (Table 4 ). On the $15^{\text {th }}$ day of storage, antioxidant activity coincides with an increase in betalain concentration. Antioxidant activity of garambullo fruits can be attributed mainly to phenolic compounds and betalains content [2].

In order to know if the phenols and the betalains, together with the ascorbic acid, are responsible for the antioxidant activity of the garambullo, a Pearson correlation coefficient was calculated and a linear correlation was found: as these compounds increased, the antioxidant activity of the fruits increased (Table 5).

Table 5. The R values (Pearson correlation coefficients) between antioxidant activities and bioactive compounds.

\begin{tabular}{ccccccc}
\hline & \multicolumn{7}{c}{ Storage Period (days) } \\
\cline { 2 - 7 } & \multicolumn{2}{c}{$\mathbf{5}$} & \multicolumn{2}{c}{$\mathbf{1 0}$} & \multicolumn{2}{c}{$\mathbf{1 5}$} \\
\cline { 2 - 7 } & DPPH & ABTS & DPPH & ABTS & DPPH & ABTS \\
\hline Betanin & 0.791 & 0.815 & 0.848 & 0.879 & 0.933 & 0.912 \\
Indicaxanthin & 0.935 & 0.975 & 0.996 & 0.985 & 0.996 & 0.997 \\
Total betalains & 0.875 & 0.907 & 0.916 & 0.937 & 0.951 & 0.933 \\
Ascorbic acid & 0.821 & 0.847 & 0.952 & 0.977 & 0.975 & 0.964 \\
Phenols & 0.892 & 0.960 & 0.985 & 0.998 & 0.959 & 0.961 \\
Flavonoids & 0.995 & 0.995 & 0.764 & 0.763 & 0.906 & 0.882 \\
\hline
\end{tabular}

Antioxidants in food are substances that counteract many oxidation reactions produced by free radicals, protecting and retarding tissue damage, reducing the loss of nutritional value and functional properties of food; thus, a high level of antioxidant activity is desirable [44]. Antioxidant activity was higher in garambullo fruits where there was a higher concentration of ascorbic acid, betalains, total phenols and flavonoids content; such values were present in garambullo fruits with gelatin-coated TOE. This indicates that gelatin coatings with TOE can not only extend fruit shelf life, but also retain antioxidant activity during storage, because the coating delays oxidation of bioactive compounds. This result could be due to the fact that TOE is rich in carotenoids such as $\beta$-carotene and lycopene mainly, which are considered excellent antioxidants due to their ability to inhibit singlet oxygen action $\left({ }^{1} \mathrm{O}_{2}\right)$ and trap peroxyl radicals (ROO ${ }^{\bullet}$ ) [14]. We can infer that the carotenoids present in TOE can act as target compounds against free radicals, and in this way increase the stability of typical bioactive compounds of garambullo fruit. In addition, it has been reported that these carotenoids, when incorporated as functional ingredients in edible gelatin-based films, improve antioxidant properties $[15,16]$. It is very likely that linseed oil, which was used as a means of extracting tomato carotenoids, also acted as an antioxidant, because it is rich in antioxidant compounds such as alpha-linolenic acid and lignans [17]. The results of this research are similar to those reported by Badawy et al. [9], who observed a higher antioxidant activity in strawberries coated with gelatin and chitosan with the addition of natural antioxidants (geraniol and thymol), than in fruits that were only coated with gelatin and chitosan.

The high antioxidant activity of garambullo fruits is due to the bioactive compounds that are synthesized in the fruits as a response to the stress of the environment in which they develop, given that Myrtillocactus geometrizans develops in arid and semi-arid zones that are not suitable for agriculture [1]. These values of antioxidant activity were higher as compared to antioxidant activity of berries such as raspberry, strawberry and cherry [4,5], as well as cacti fruits, such as pitaya [45]. Gelatin coatings with TOE represent a viable alternative to preservation of the antioxidant properties of garambullo fruits during storage at $5 \pm 1{ }^{\circ} \mathrm{C}$. 


\section{Conclusions}

The results of this research show that gelatin coatings incorporated with tomato oily extracts are highly efficient in protecting garambullo fruits that are in storage at $5{ }^{\circ} \mathrm{C}$. The coatings are able to limit both weight loss and changes in physicochemical parameters such as ${ }^{\circ} \mathrm{Bx}, \mathrm{pH}, \mathrm{TA}$, and color. Gelatin coatings with TOE had a positive effect by inducing a higher content of betalains, ascorbic acid, total phenols and flavonoids; therefore, they have higher antioxidant activity as compared to the control. Gelatin-based coatings with TOE-3\% (COTE-3\%) was the most effective for preserving bioactive compounds and quality of garambullo fruits. Gelatin-based coatings with tomato oily extract preserve phytochemicals contained in garambullo fruits, which is an excellent source of antioxidants in the human diet. Further studies are needed to investigate the sensorial acceptance of gelatin-based coatings.

Author Contributions: C.U.L.-P., C.L.A.-M., J.C.R.-P., J.G.R.-P., and A.D.H.-F. conceived and designed the experiments, and wrote the paper.; J.G.-T., and C.U.L.-P. performed the laboratory analyses and analyzed the data; A.D.H.-F. contributed the reagents and materials. All authors were responsible for processing information and manuscript writing. All authors read and approved the final manuscript.

Funding: This research received no external funding.

Acknowledgments: The main author thanks the National Council for Science and Technology (CONACyT, Mexico) for scholarship No. 402763 for graduate studies in Agri-Food Production Science at the TecNM-Instituto Tecnologico de Roque.

Conflicts of Interest: The authors declare no conflict of interest.

\section{References}

1. Hernández-López, D.; Vaillant, F.; Reynoso-Camacho, R.; Guzman-Maldonado, S.-H. Myrtillocactus (Cactaceae): Botanical, agronomic, physicochemical and chemical characteristics of fruits. Fruits 2008, 63, 269-276. [CrossRef]

2. Herrera-Hernández, M.G.; Guevara-Lara, F.; Reynoso-Camacho, R.; Guzmán-Maldonado, S.H. Effects of maturity stage and storage on cactus berry (Myrtillocactus geometrizans) phenolics, vitamin c, betalains and their antioxidant properties. Food Chem. 2011, 129, 1744-1750. [CrossRef]

3. Guzmán-Maldonado, S.H.; Herrera-Hernández, G.; Hernández-López, D.; Reynoso-Camacho, R.; Guzmán-Tovar, A.; Vaillant, F.; Brat, P. Physicochemical, nutritional and functional characteristics of two underutilised fruit cactus species (Myrtillocactus) produced in central Mexico. Food Chem. 2010, 121, 381-386. [CrossRef]

4. Santiago-Mora, P.D.; Cardador-Martinez, A.; Tellez-Perez, C.; Montejano-Gaitan, J.G.; Martin del Campo, S.T. In Vitro Antioxidant capacity and bioactive compounds preservation post-drying on berrycacti (Myrtillocactus Geometrizans). J. Food Res. 2017, 6, 121-133. [CrossRef]

5. Pellegrini, N.; Serafini, M.; Colombi, B.; Del Rio, D.; Salvatore, S.; Bianchi, M.; Brighenti, F. Total antioxidant capacity of plant foods, beverages and oils consumed in italy assessed by three different in vitro assays. J. Nutr. 2003, 133, 2812-2819. [CrossRef] [PubMed]

6. Correa-Betanzo, J.; Jacob, J.K.; Perez-Perez, C.; Paliyath, G. Effect of a sodium caseinate edible coating on berry cactus fruit (Myrtillocactus Geometrizans) phytochemicals. Food Res. Int. 2011, 44, 1897-1904. [CrossRef]

7. Dhall, R.K. Advances in edible coatings for fresh fruits and vegetables: A review. Crit. Rev. Food Sci. Nutr. 2013, 53, 435-450. [CrossRef] [PubMed]

8. Etxabide, A.; Uranga, J.; Guerrero, P.; de la Caba, K. Development of active gelatin films by means of valorisation of food processing waste: A review. Food Hydrocoll. 2017, 68, 192-198. [CrossRef]

9. Badawy, M.E.I.; Rabea, E.I.; El-Nouby, M.A.M.; Ismail, R.I.A.; Taktak, N.E.M. Strawberry shelf life, composition, and enzymes activity in response to edible chitosan coatings. Int. J. Fruit Sci. 2017, 17, 117-136. [CrossRef]

10. Gol, N.B.; Rao, T.V. Influence of zein and gelatin coatings on the postharvest quality and shelf life extension of mango (Mangifera Indica L.). Fruits 2013, 69, 101-115. [CrossRef]

11. Radi, M.; Firouzi, E.; Akhavan, H.; Amiri, S. Effect of gelatin-based edible coatings incorporated with aloe vera and black and green tea extracts on the shelf life of fresh-cut oranges. J. Food Qual. 2017. [CrossRef] 
12. Andrade, R.; Skurtys, O.; Osorio, F.; Zuluaga, R.; Gañán, P.; Castro, C. Wettability of gelatin coating formulations containing cellulose nanofibers on banana and eggplant epicarps. LWT-Food Sci. Technol. 2014, 58, 158-165. [CrossRef]

13. Borguini, R.G.; da Silva Torres, E.A.F. Tomatoes and tomato products as dietary sources of antioxidants. Food Rev. Int. 2009, 25, 313-325. [CrossRef]

14. Oroian, M.; Escriche, I. Antioxidants: Characterization, natural sources, extraction and analysis. Food Res. Int. 2015, 74, 10-36. [CrossRef] [PubMed]

15. Januario, M.M.S.; Sobral, P.J.A.; Trindade, C.S.F.; Carvalho, R.A. Gelatin films with lycopene: Mechanical, water vapor barrier, color, and light barrier properties. Ital. J. Food Sci. 2009, 21, 126-129.

16. Gómez-Estaca, J.; Calvo, M.M.; Sánchez-Faure, A.; Montero, P.; Gómez-Guillén, M.C. Development, properties, and stability of antioxidant shrimp muscle protein films incorporating carotenoid-containing extracts from food by-products. LWT-Food Sci. Technol. 2015, 64, 189-196. [CrossRef]

17. Brodowska, K.; Catthoor, R.; Brodowska, A.J.; Symonowicz, M.; Łodyga-Chruścińska, E.; Student, P.D. A Comparison of antioxidant properties of extracts from defatted and non-defatted flax (Linum Usitatissimum) Seeds. Albanian J. Agric. Sci. 2014, 13, 16-23. [CrossRef]

18. Alparslan, Y.; Baygar, T.; Baygar, T.; Hasanhocaoglu, H.; Metin, C. Effects of gelatin-based edible films enriched with laurel essential oil on the quality of rainbow trout (Oncorhynchus mykiss) fillets during refrigerated storage. Food Technol. Biotechnol. 2014, 52, 325-333.

19. Juárez-Maldonado, A.; Ortega-Ortíz, H.; Cadenas-Pliego, G.; Valdés-Reyna, J.; Pinedo-Espinoza, J.; López-Palestina, C.; Hernández-Fuentes, A.; Juárez-Maldonado, A.; Ortega-Ortíz, H.; Cadenas-Pliego, G. Foliar application of cu nanoparticles modified the content of bioactive compounds in moringa Oleifera Lam. Agronomy 2018, 8, 167. [CrossRef]

20. AOAC International. Official Methods of Analysis of AOAC International; AOAC International: Rockville, MD, USA, 1995.

21. Monroy-gutiérrez, T.; Martínez-damián, M.T.; Barrientos-priego, A.F.; Gallegos-vázquez, C.; Colinas-león, T.B. Evaluation of some physical and chemical characteristics of fruits of xocotuna, tuna and xoconostle in postharvest. Rev. Mex. Cienc. Agríc. 2017, 8, 189-197. [CrossRef]

22. Dürüst, N.; Sümengen, D.; Dürüst, Y. Ascorbic acid and element contents of food of trabzon (Turkey). J. Agric. Food Chem. 1997, 8561, 2085-2087. [CrossRef]

23. Rosales, M.A.; Cervilla, L.M.; Sánchez-Rodríguez, E.; del Mar Rubio-Wilhelmi, M.; Blasco, B.; Ríos, J.J.; Soriano, T.; Castilla, N.; Romero, L.; et al. The effect of environmental conditions on nutritional quality of cherry tomato fruits: Evaluation of two experimental mediterranean greenhouses. J. Sci. Food Agric. 2011, 91, 152-162. [CrossRef] [PubMed]

24. Brand-Williams, W.; Cuvelier, M.E.; Berset, C. Use of a free radical method to evaluate antioxidant activity. LWT-Food Sci. Technol. 1995, 28, 25-30. [CrossRef]

25. Re, R.; Pellegrini, N.; Proteggente, A.; Pannala, A.; Yang, M.; Rice-Evans, C. Antioxidant activity applying an improved abts radical cation decolorization assay. Free Radic. Biol. Med. 1999, 26, 1231-1237. [CrossRef]

26. Ullah, A.; Abbasi, N.A.; Shafique, M.; Qureshi, A.A. Influence of edible coatings on biochemical fruit quality and storage life of bell pepper cv. "Yolo Wonder". J. Food Qual. 2017. [CrossRef]

27. Tongnuanchan, P.; Benjakul, S.; Prodpran, T. Properties and antioxidant activity of fish skin gelatin film incorporated with citrus essential oils. Food Chem. 2012, 134, 1571-1579. [CrossRef] [PubMed]

28. Aitboulahsen, M.; Zantar, S.; Laglaoui, A.; Chairi, H.; Arakrak, A.; Bakkali, M.; Zerrouk, M.H. Gelatin-based edible coating combined with mentha pulegium essential oil as bioactive packaging for strawberries. J. Food Qual. 2018. [CrossRef]

29. De La Barrera, E.; Nobel, P.S. Carbon and water relations for developing fruits of Opuntia ficus-indica (L.) miller, including effects of drought and gibberellic acid. J. Exp. Bot. 2004, 55, 719-729. [CrossRef] [PubMed]

30. Moussa-Ayoub, T.E.; Jaeger, H.; Youssef, K.; Knorr, D.; El-Samahy, S.; Kroh, L.W.; Rohn, S. Technological Characteristics and selected bioactive compounds of opuntia dillenii cactus fruit juice following the impact of pulsed electric field pre-treatment. Food Chem. 2016, 210, 249-261. [CrossRef] [PubMed]

31. Reynoso, R.; Garcia, F.A.; Morales, D.; Gonzalez De Mejia, E. Stability of betalain pigments from a cactacea fruit. J. Agric. Food Chem. 1997, 45, 2884-2889. [CrossRef] 
32. Stintzing, F.C.; Schieber, A.; Carle, R. Identification of betalains from yellow beet (Beta Vulgaris L.) and cactus pear [Opuntia Ficus-Indica (L.) Mill.] by high-performance liquid chromatography-electrospray ionization mass spectrometry. J. Agric. Food Chem. 2002, 50, 2302-2307. [CrossRef] [PubMed]

33. Ramírez-Ramos, M.; del Rosario García-Mateos, M.; Corrales-García, J.; Ybarra-Moncada, C.; Castillo-González, A.M. Compuestos antioxidantes en variedades pigmentadas de tuna (Opuntia sp.). Rev. Fitotec. Mex. 2015, 38, 349-357.

34. Sumaya-Martínez, M.T.; Cruz-Jaime, S.; Madrigal-Santillán, E.; García-Paredes, J.D.; Cariño-Cortés, R.; Cruz-Cansino, N.; Valadez-Vega, C.; Martinez-Cardenas, L.; Alanís-García, E. Betalain, acid ascorbic, phenolic contents and antioxidant properties of purple, red, yellow and white cactus pears. Int. J. Mol. Sci. 2011, 12, 6452-6468. [CrossRef] [PubMed]

35. Barba, F.J.; Putnik, P.; Bursać Kovačević, D.; Poojary, M.M.; Roohinejad, S.; Lorenzo, J.M.; Koubaa, M. Impact of conventional and non-conventional processing on prickly pear (Opuntia spp.) and their derived products: From preservation of beverages to valorization of by-products. Trends Food Sci. Technol. 2017, 67, 260-270. [CrossRef]

36. Azeredo, H.M.C. Betalains: Properties, sources, applications, and stability-A review. Int. J. Food Sci. Technol. 2009, 44, 2365-2376. [CrossRef]

37. Rodriguez-Amaya, D.B. Food Carotenoids: Analysis, composition and alterations during storage and processing of foods. Forum Nutr. 2002, 56, 35-37.

38. Mditshwa, A.; Samukelo, L.; Zeray, S.; Linus, U. Scientia horticulturae postharvest factors affecting vitamin c content of citrus fruits: A review. Sci. Hortic. (Amsterdam) 2017, 218, 95-104. [CrossRef]

39. Sanchez-Gonzalez, L.; Pastor, C.; Vargas, M.; Chiralt, A.; Gonzalez-Martinez, C.; Chafer, M. Effect of hydroxypropylmethylcellulose and chitosan coatings with and without bergamot essential oil on quality and safety of cold-stored grapes. Postharvest Biol. Technol. 2011, 60, 57-63. [CrossRef]

40. Meng, X.; Li, B.; Liu, J.; Tian, S. Physiological responses and quality attributes of table grape fruit to chitosan preharvest spray and postharvest coating during storage. Food Chem. 2008, 106, 501-508. [CrossRef]

41. Adiletta, G.; Pasquariello, M.; Zampella, L.; Mastrobuoni, F.; Scortichini, M.; Petriccione, M. Chitosan coating: A postharvest treatment to delay oxidative stress in loquat fruits during cold storage. Agronomy 2018, 8, 54 . [CrossRef]

42. Rice-Evans, C.A.; Miller, N.J.; Paganga, G. Structure-antioxidant activity relationships of flavonoids and phenolic acids. Free Radic. Biol. Med. 1996, 20, 933-956. [CrossRef]

43. Fukumoto, L.R.; Mazza, G. Assessing antioxidant and prooxidant activities of phenolic compounds. J. Agric. Food Chem. 2000, 48, 3597-3604. [CrossRef] [PubMed]

44. Ramkumar, M.; Rajasankar, S. Analysis of total phenolics and antioxidant activity of alcoholic and aqueous extract of south indian curcuma longa rhizomes. Int. J. Pharma Bio. Sci. 2016, 7, 284-287. [CrossRef]

45. García-Cruz, L.; Valle-Guadarrama, S.; Salinas-Moreno, Y.; Luna-Morales, C.D.C. Postharvest quality, soluble phenols, betalains content, and antioxidant Activity of Stenocereus pruinosus and Stenocereus stellatus fruit. Postharvest Biol. Technol. 2016, 111, 69-76. [CrossRef]

(C) 2018 by the authors. Licensee MDPI, Basel, Switzerland. This article is an open access article distributed under the terms and conditions of the Creative Commons Attribution (CC BY) license (http:// creativecommons.org/licenses/by/4.0/). 